\title{
Big flies have bigger cells
}

\section{R. McNeill Alexander}

IT is generally assumed that related animals of different sizes have similar-sized cells. The red blood cells of mammals are often quoted as an example: their diameters are about $8 \mu \mathrm{m}$, both in shrews and in humpback whales ${ }^{1}$.

However, R. D. Stevenson and his colleagues $^{2}$ have now shown that bigger fruitflies have markedly bigger cells. They studied the Drosophila species of Hawaii, which range in length from a smallish 2 $\mathrm{mm}$ to a giant $8 \mathrm{~mm}$. Sensibly, they chose to measure cells whose sizes are apparent from the fly's external morphology. They inferred the sizes of cells in the wings from the spacing of hairs (there is one hair for each cell); the sizes of photoreceptors from the sizes of the facets of the eye; and those of cells in the feet from the spacing of bristles (alternate cells carry a bristle). In each case, the $2 \mathrm{~mm}$ flies had (roughly) $15 \mu \mathrm{m}$ cells and the $8 \mathrm{~mm}$ flies had $25 \mu \mathrm{m}$ cells.

There are limits to the range of feasible sizes for a cell. It must be large enough to contain the genome (and salamanders with exceptionally large genomes have larger brain cells than others with smaller genomes ${ }^{3}$ ), but not so large that the nucleus cannot control it.

Knowledge of cell size is critically important for understanding the allometry of some organs. Consider, for example, the gills of fishes, whose lamellae consist of two sheets of epithelial cells linked by pillar cells. Blood flows through the space between the two sheets, which is just wide enough to allow red cells to pass. As for other groups of animals, the metabolic rates of fishes are roughly proportional to (body mass) $^{0.75}$ (ref. 4). How can the gills of fishes of different sizes take up oxygen at the appropriate rates?

Suppose first that fishes of different sizes are geometrically similar, with cell diameters (and gill filament thicknesses and spacing) proportional to body length, or to (body mass) ${ }^{0.33}$. Gill area will be proportional to length squared, or to (body mass) $^{0.67}$. Oxygen will diffuse into the blood at a rate proportional to gill area and inversely proportional to diffusion distance - that is, at a rate proportional

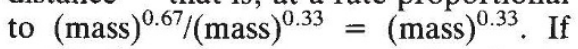
metabolic rate is proportional to (mass $)^{0.75}$, then big fish will be short of oxygen.

Now suppose instead that differentsized fishes have gills built from cells of equal size. The thickness of the gill lamellae will be constant, and we can expect their spacing also to be constant so that the ratio of the pressure needed to pump water over the gills, to that needed to pump blood through them, will be con- stant. In that case gill area will be proportional to the volume of the gills, or to body mass, and diffusion distance will be constant. Oxygen will diffuse in at a rate proportional to (body mass) ${ }^{1.00} /$ (body mass $)^{0}$, that is to body mass. With this set of assumptions it is the small fish that will be in trouble, if metabolic rate is proportional to (body mass) $)^{0.75}$.

To get diffusion rates proportional to (body mass) ${ }^{0.75}$, cell size and the dimensions of the lamellae should be proportional to (body mass) $)^{0.125}$. Observed exponents are less than this, 0.02 and 0.09 in ontogenetic series for two species ${ }^{5}$. Stevenson et al. ${ }^{2}$ relate fruitfly cell diameters to the length rather than the mass of the body, but from their data it can be estimated that cell diameters are proportional to body mass with exponents between 0.11 and 0.17 .

Now we realize that cell size may vary allometrically, we may expect it to be optimized. Barlow's classic argument ${ }^{6}$ describes what this might involve in the compound eyes of insects. These must have small facets, to be capable of seeing fine detail. But excessively small facets will be less good at resolving detail, because diffraction makes them less directionally selective. The best compromise is to have facet (and receptor cell) diameters proportional to the square root of eye diameter. Barlow found that the eyes of bees and wasps scaled almost as predicted. Stevenson et al. ${ }^{2}$ find that facet diameter in Drosophila eyes is proportional to (eye diameter $)^{0.68} \pm 0.21$.

Attempts to predict optimum allometric relationships are plagued by the problem of excessive numbers of variables. Geometric similarity and elastic similarity ${ }^{7}$ are convenient simplifying assumptions in some cases, but are often contravened. Constancy of cell size seemed highly attractive, as an assumption that might be widely applicable. But it is now clear that it should not be made blindly.

R. McNeill Alexander is in the Department of Pure and Applied Biology, University of Leeds, Leeds LS2 9JT, UK.

1. Altman, P. L. \& Dittmer, D. S. Blood and Other Body Fluids (Federation of American Societies for Experimental Biology, Bethesda, 1961)

2. Stevenson, R. D., Hill, M. F. \& Bryant, P. J. Proc. R. Soc. Lond. B259, 105-110 (1995).

3. Roth, G., Rottluff, B. \& Linke, R. Naturwissenschaften $\mathbf{7 5}$. 297-304 (1988)

4. Calder, W. A. Size, Function and Life History (Harvard Univ. Press, Cambridge, MA, 1984)

5. Hughes, G. M. in Scale Effects in Animal Locomotion (ed. Pedley, T. J.) 57-81 (Academic, London, 1977)

6. Barlow, H. B. J. exp. Biol. 29, 667-674 (1952).

7. McMahon. T. A. \& Bonner, J. T. On Size and Life (Scientific American Library, New York, 1983).

\section{DAEDALUS \\ The social market}

LAST week Daedalus proposed that students should be supported, not by grants or loans, but by shares. He is now taking this scheme to its ultimate conclusion, combining capitalism and communitarianism. Every human activity, he says, should be directed not by ideologies but by market forces, and funded not by taxation but by shares.

A newborn baby, for example, can be regarded as a promising technical project in a very early stage. It will make a profit only after years of development. At present, the parents may back it with their own resources, or depend on State benefits. Their quality of management can vary wildly, and may be very poor as with a deprived single mother.

But suppose such a mother, instead of relying on the State, has to fund her offspring by issuing share capital in it. To attract investors, she will have to bring it up as best she can, keep it out of crime and not burden her portfolio with further potential loss-makers. If she fails, the child's share price will decline, and it may be taken over by another mother or a specialized institution which can manage it better.

When the child finally grows up, he will pay dividends to his shareholders. This need not be much of a burden. Nearly all State spending these days goes on benefits and entitlements; once these are abolished, income tax can go as well, with the purely personal dividend in its place. The sound financial discipline which constrained the parents will now devolve upon the offspring. If he seems not to be fulfilling his potential, his share price will suffer, and he will find it hard to raise capital for projects of his own. If he goes seriously to the bad, he will probably be taken over and turned round by some firm specializing in rescuing bad risks such as dead-end kids, drifters and midlife crisists. An efficient market solution will supersede clumsy, costly social services.

Even in old age, he need not suffer. During his productive lifetime, he will himself have bought stock in the next generation of children. Their dividends will be his pension, and he will trade mainly as a holding company.

At every stage in life, his shareholders will be there, providing support and discipline: backers, managers and godfathers combined. The incompetent State will be rolled right back, replaced by a collective social market which will grow ever shrewder and more efficient as it gains experience. And our modern, dangerously diverse society will be unified and harmonized, as each member acquires multiple financial interests in all the others. David Jones 